University of Louisville

ThinkIR: The University of Louisville's Institutional Repository

\title{
Greening Gawain : connecting environmental damage and masculinity in Sir Gawain and the green knight.
}

\author{
Austin Putty \\ University of Louisville
}

Follow this and additional works at: https://ir.library.louisville.edu/honors

Part of the Feminist, Gender, and Sexuality Studies Commons, Literature in English, British Isles Commons, and the Medieval Studies Commons

\section{Recommended Citation}

Putty, Austin, "Greening Gawain : connecting environmental damage and masculinity in Sir Gawain and the green knight." (2017). College of Arts \& Sciences Senior Honors Theses. Paper 143.

http://doi.org/10.18297/honors/143

This Senior Honors Thesis is brought to you for free and open access by the College of Arts \& Sciences at ThinkIR: The University of Louisville's Institutional Repository. It has been accepted for inclusion in College of Arts \& Sciences Senior Honors Theses by an authorized administrator of ThinkIR: The University of Louisville's Institutional Repository. This title appears here courtesy of the author, who has retained all other copyrights. For more information, please contact thinkir@louisville.edu. 
Greening Gawain:

Connecting Environmental Damage and Masculinity in Sir Gawain and the Green Knight

By

Austin Putty

Submitted in partial fulfillment of the requirements

for Graduation summa cum laude

and

for Graduation with Honors from the Department of English

University of Louisville

May, 2017 
Climate change is the most complex and universal threat that humanity has ever faced. Although scientists have reached a consensus in recognizing the great challenge looming before the whole of humanity, leaders in politics and business, especially in the United States, have not adequately met the challenge of global climate change and global environmental change. Where natural science fails, criticism, social science, and art must step in both to analyze factors surrounding the reluctance to action, and strategically motivate those resistant to the cause. In Ecocriticism, Greg Garrard recognizes the need for such endeavors, especially concerning issues of global importance. It "demands a politicized reading practice more akin to social ecology and Cultural Studies than to deep ecology and traditional literary studies" (Garrard 162). In order to confront the issue of the United States' slow response to tackling global climate change, one must identify the discourses at work, identifiable in literature and other cultural artifacts, which resist the long-term, sustainable thinking that is needed to face the issues of today and tomorrow. In American politics, that problem is unequivocally climate change denial.

Garrard describes the need for cultural producers to utilize tropes and metaphors to impart those now necessary environmentally minded values in ways that scientists cannot. He simultaneously notes that these signifiers must be critically understood, even those utilized to destroy the credibility of science, for they are the key toward developing precise messaging that reaches resistant subjects.

Breaking these monolithic concepts down into key structuring metaphors, or tropes, enables attention to be paid to the thematic, historical and geographical particularities of environmental discourse, and reveals that any environmental trope is susceptible to appropriation and deployment in the service of a variety of potentially conflicting interests. Ecocriticism makes it possible to analyze critically the tropes brought into play 
in environmental debate, and, more tentatively, to predict which will have a desired effect on a specific audience at a given historical juncture. (Garrard 14)

In the genre of English medieval chivalric romance, critics have poured in their faculties toward the question of modernity; that is, at what point in our cultural history does the medieval end, and the modern begin? Cultural critics have employed perspectives from a variety of disciplines to identify, through close readings of romance texts, the changing, conflicting discourses that constitute the transition. One could argue that a central component of the contemporary condition is the ecological awareness that has developed, especially in the last 50 years, thanks to radical advances in biology, computational technology, climatology, and the other earth sciences. It comes as a surprise then, with today's booming field of eco-criticism, that comparatively little work has been directed towards a green reading of chivalric texts.

This is not to say that no work has been done on the subject. We can look to the pivotal works of many environmental historians who have delivered profound overviews of the transition in Western attitudes toward nature. For example, Keith Thomas in Man and the Natural World describes the transition from an adversarial, anthropocentric, and biblical worldview towards the development of gardening as a pastime and animal rights in Victorian England. In The Death of Nature, eco-feminist Carolyn Merchant understands the transition as a movement from a "daily, immediate, organic relation with nature" to the Enlightenment machine metaphor, the inanimate quality of which "could legitimate the manipulation of nature," also connecting it to the patriarchal domination of women (Merchant 1, 193). Of environmental historians, perhaps the freshest perspective this research has encountered comes from John Aberth's An Environmental History of the Middle Ages: The Crucible of Nature. Working against the dominant discourse of an originally adversarial relationship of man against nature, 
Aberth claims the peoples of medieval Europe, through the numerous environmental disasters and shakeups of the period, especially considering the bubonic plague, multiple famines, habitat destruction from war, the Little Ice Age, and mass deforestation; that "man's actions were understood to be able to shape and impact the environment, which then redounds back onto him" (Aberth 2). Perhaps medieval Europe held a greater awareness of the ecological relationship between humanity and nature than historians have previously credited; they simply lacked the means of describing it that would come with the scientific knowledge of later centuries. Additionally, medieval scholars are not solidified on a starting point for modernity. The argument is where the transition begins, and for Aberth to state such an early ecological awareness calls into question the historicism of ecological thought in its relation to modernity.

Aldo Leopold, in his 1948 essay, "The Land Ethic," describes the development of an increased societal moral consciousness that has, throughout history, expanded to meet the needs of an increasingly interdependent human creature, putting it in somewhat scientific terms as, "an evolutionary possibility and an ecological necessity" (Leopold 63). Its development replaces "free-for-all competition" with "co-operative mechanisms with an ethical content," and Leopold describes an ethic as "a limitation on the freedom of action in the struggle for existence" (62). The concept of an ethic as a limitation suggests that humans can only benefit nature by leaving it alone, reinforcing the idea that nature and human are inherently oppositional. After the first two stages of ethical development, which relate to man's interactions with other individuals, and then interactions with society, respectively, Leopold argues that man's - he uses the male gendered pronoun collectively, indicating that his own ethic may need to expand to include women and other gender identities - third step in this sequence of ethical evolution is the development of a land ethic, which "simply enlarges the boundaries of the community to include soils, waters, 
plants, and animals, or collectively; the land" (64). Humans, under the land ethic, are converted "from conqueror of the land-community to plain member and citizen of it" (64).

Although we live in an era of unprecedented concern for the environment and bestow the greatest government protections upon the non-human to date, clearly, we have not, as a societal whole in the United States, fully adopted Leopold's land ethic. In accordance with the principles of new historicism, this paper will not assume historical progress exists as a linear succession of improvement. In Leopold's time, ecological sciences adhered to the concept of inter-related wholeness, where ecosystems transitioned sequentially from one stage of succession toward a climax state of equilibrium. Wilderness was believed to be able to regulate itself toward a state of balance if only left alone. The new ecology of the late twentieth century, taking lessons from highly mathematical population experiments, contradicted that former notion as it discovered the state of ecosystems are highly subject to the influence of chance. New ecologists, it seems, have mirrored the claims of postmodernist historical and literary critics in the conclusion that unified ecosystem concepts - almost a master narrative for naturalists - fail to portray the reality, since ecosystems are rarely ever at an orderly and whole state, and that extinction and chaotic change are the rule rather than exception. This does not excuse the tremendous stress humans are placing on the planet, however, which is causing massive ecosystem decay well beyond natural cycles and processes. While different habitats blend into each other by gradients of temperature, moisture content, and other factors, they are also increasingly fragmented by human infrastructure and activity. David Quammen explores the topics of island biogeography and extinction in Song of the Dodo, discussing how islands, as essentially fragmented habitats, are drivers of both evolution and extinction. Likewise, the mainland can also be understood as a marginally connected and disconnected chain of habitat-islands. "Geographic isolation is the 
flywheel of evolution," he writes, but also that human development is cutting up habitats into chunks too small to support critical species, causing rippling effects down the trophic pyramid (Quammen 128). "The world is in pieces," he declares (549). What this means for the land ethic is that it is ultimately an unobtainable goal to have the whole of humanity onboard, considering everyone is an island of consciousness unto themselves. What's regrettable is that the 'bad behavioral adaptations' of a select population will eventually hurt our species in its entirety. Even those who champion the non-human have failed to fully adopt the land ethic. For example, deep ecology, a modern environmental discourse, understands humans horizontally to nature, in terms of inherent value, and views humans as both an extension of nature and part of the environment as highly evolved animals, in effect eliminating the anthropocentric divide between the human and the natural. In practice, it is impossible to always equally compromise between human and non-human interests - especially since non-human interests must be represented by humans to other humans, with all the bias that encompasses such an endeavor - deep ecology's proponents are often criticized as too apathetic towards humanity, promoting a lop-sided land ethic that disfavors the human, disregarding the first and second stages of Leopold's moral evolution. As Leopold himself wrote, "we still slip two steps backward for each forward stride" (67).

Revisiting Leopold's use of "man" as a collective pronoun - there is something profound hidden in it. Leopold, perhaps unaware of it himself, identified the essential problem. In the United States, masculinity is still defined and expressed in terms of rugged individualism - a mode of self-assertion rooted in the idea of overcoming one's surroundings to achieve one's goals. The process of becoming an environmental, ecological citizen requires the retirement of the conqueror mindset, which is a patriarchal expression of masculine dominance; in other 
words, environmentalism is emasculating, explaining why some value the commercial exploitation of resources over acting on environmental issues, despite the cries of science. To go from conqueror to citizen is understood as voluntary emasculation, which is a concession of patriarchal privilege. Of course, the transition from conqueror to citizen, which is essentially just an increase in mindfulness, does not have to be emasculating, but people tend to dislike change, and will certainly seek to avoid a masculine identity crisis. Feminist and gender critics describe certain self-destructive modes of masculinity as toxic masculinity, so I wish to recycle the term to indicate a conceptualization and performance of masculinity that causes damage to the environment, which includes the human and the non-human communities. Toxic masculinity encourages resource exploitation, consumerism, and other economic interests in the quest of capitalist self-realization over communal responsibility and belonging. Its behaviors stem from the desire to express dominance as a means of identity and reputability, leading its practitioners on a warpath against their physical and social environment.

Social scientists have recently been identifying this trend in survey and case studies. For example, researchers on behalf of the Journal of Consumer Research recently studied the link between consumers' perceptions of green products and their likelihood to purchase them by sex. The results of seven different studies found "greenness and femininity are cognitively linked and shows that, accordingly, consumers who engage in green behaviors are stereotyped by others as more feminine and even perceive themselves as more feminine," and also that men seeking to preserve their image of masculinity may avoid sustainable behaviors and products (Brough et al. 567). Men might also seek to protect economic, political, and social privileges, such as those national and state legislators who take lobby money and campaign donations from fossil fuel companies in exchange for frustrating the creation of effective environmental policy; however, in 
some cases men will support environmentally harmful practices that do not - or used to, but no longer - directly benefit them. Shannon Bell and Yvonne Braun, in their 2010 study, identify a "culture of silence" around men in Appalachian mining communities that discourages male involvement, even among those working outside of the mines, in environmental justice movements that call into question the actions of the coal companies and operations that have exploited their communities (806).

Men's intimate ties to the coal industry and the privilege these ties afford them within the community may discourage them from taking a critical position against coal-related injustices, for fear that such a position could bring marginalization and a loss of status. ... the decline in coal jobs has meant that coal-related hegemonic masculine identity is under threat. Thus, for coalfield men, speaking out against the coal industry not only means speaking out against a potential employer; it may also mean a further threat to an already-vulnerable masculine identity. (Bell and Braun, 806-07, 810)

In coal communities, men are afraid of losing their identities as miners and bread providers because coal is losing out to cheaper natural gas and renewables in the energy market. Because coal mining has historically offered the only viable job for men in Appalachia, the community lacks alternative means of expressing something akin to a traditional masculine identity. Were there alternatives, men wouldn't feel as threatened by the repudiation of coal from their communities. Bell and Braun, regarding the activist men sampled in their Appalachian study, report that "certain life events and circumstances have affected the personal identities of these men in ways that have rendered the local hegemonic masculinity of the coalfields less relevant to their self-conception," which has allowed these outliers to identify with the environmental justice 
movement (810). It shows that transformation is possible, and it is happening already; however, it is a project that requires ongoing work.

In general, most men are not confronting a masculine-identity crisis of the same exigency as the Appalachian coal miners. The thread in common, however, is the lack of available, appealing alternatives on which to create a masculinity that incorporates a land ethic or some variation of it. Detoxifying masculinity must also go beyond just alleviating the stress it places on the non-human environment; it needs to also improve relations with other humans and human institutions, incorporating all stages of Leopold's moral evolution. Detoxified masculinity will not find its answer in existing tropes like outdoorsman masculinity either, as hunting and 'roughing it' are ways of expressing dominance over nature. Detoxified masculinity needs to show how citizenry is empowering and validating, but also demands inclusion.

It is in this context that I wish to discuss Sir Gawain and the Green Knight (SGGK, henceforth), a medieval romance poem written in the late-fourteenth century by an anonymous poet, often referred to as the Pearl Poet for his other famous work. $S G G K$ provides a blueprint for what may be a method of combating climate change denial at its cultural roots, which I will argue in this paper stems from an outdated mode of European warrior masculinity. This paper will demonstrate toxic masculinity, as defined regarding environmentally damaging attitudes and practices - the definition of environment including both human and non-human spheres - at work as a discourse in $S G G K$ through chivalric behaviors, as well as a burgeoning environmental conscientiousness at play that undermines it. Although the poet of $S G G K$ does not directly seek to incorporate Leopold's land ethic throughout the text, he does seek to renegotiate certain aspects of chivalric masculinity, and it is through this negotiation that a developing land ethic works its way into the text; however, the poet, and late-fourteenth century England, lack the 
discourse necessary to delineate this incubating land ethic, the language for which has only developed in the last century. The conflict between Gawain and the Green Knight is a struggle to detoxify certain elements of chivalric warrior masculinity, and through a close reading of the text we can relate this project towards today's goal of countering the specifically male-resistance toward embracing sustainability, making 'green' friendlier to masculine identities. The paper will end with a short analysis of two modern films that recall and update elements of the male romance protagonist, and even the structure of romance itself.

The signifying courtly behaviors that constitute toxic masculinity are established in the opening of the poem, during Camelot's Christmas celebration, setting up a chivalric discourse of masculinity and place that the Green Knight and Hautdesert overturn later in the poem. Throughout $S G G K$ readers will find the typical chivalric path as taken by Gawain, a representative of King Arthur's court, challenged through the Green Knight and his trials. The poem opens with a brief history of England that is marked by violence, dating Britain's origins back to the Trojan War. The narrator states that chivalric violence provides the Christmas festival's entertainment, as "Knights day after day rode / In tourneys, jousted gallant and well" (SGGK 41-42). Arthur stalls the Christmas feast, per his custom, until he enjoys some "marvel," whether that be "a tale of adventures" or "a courtly visitor" to challenge one of his knights to "Fight for his life, man against man, / as fate determined" (94-99). Arthur is so adamant about this tradition that he considers it "a point of honor," which he has actually taken as a vow, whether to himself or another party we do not know (90-91). That he regularly demands such entertainment before holding each and every court indicates an intentional effort to sustain the practice of violence. To fight and abide by the outcome of fate in battle implies that the only veritable power in the politics of $S G G K$ is violence; anything else, chivalry included, is a custom 
of displaying and exercising that power. As the saying goes, 'might makes right,' and this is especially true in a Christian society where fate was believed to be controlled by God. The outcome of a death-match could be understood as a litmus test for whoever was the holiest or most righteous knight, since God's favored servant would certainly be blessed with victory. While the opening stanzas establish violence as a knightly way of interacting with the world, it also celebrates and foreshadows a trickster figure in "Aeneas the noble," "whose tricks had taken / Troy For the Greeks," (3-4) and Brutus, the most famous backstabber in history, whose governance made "Britain grew rich" (20). The Green Knight will come along, like Aeneas and Brutus, to undermine the establishment by challenging the most basic chivalric conventions, especially that of the duel, with the game of beheading. Although the true trial of the Green Knight manifests in Sir Bercilak's prize exchange, it is guised in the violence of the Green Knight's exchange of blows.

Violence is the foremost chivalric behavior that constitutes toxic masculinity because it is an inherently oppositional method of interacting with the world. Citizens do not practice violence, but conquerors do. Violence is the power by which the militarized aristocracy preserves its dominance. Carl Martin argues in "The Cipher of Chivalry" that courtly violence operates on a different plane of depoliticized space, unlike regular war. As such, jousts, tourneys, or even beheading challenges could be treated as play. Despite the high risk of injury, these games could be treated as an exhibition match without political consequence.

... aristocratic violence, no matter how extensive and consequential, is autonomized, stripped of its determinants and effects, insulated, set apart, accountable only to itself and strictly according to its own criteria as an exceptional kind of activity within a privileged Huizingan circle of play - chivalry. Indeed, chivalry was ultimately no more than the 
circle of its own careful delineation, a cipher marking an empty space, a signifier without a determinable essence, meaning, or goal... Whatever its specific form, origin, and aim, chivalry was whatever its enthusiasts wanted it to be, accommodating and ennobling all sorts of martial action, no matter how objectless, imprudent, or predatory. (Martin 323) As Martin indicates, aristocrats could extend the no-consequence universe of courtly violence to justify any scenario they needed, and one such predation is against the natural world. The trials of $S G G K$ are simply a reversal of the violence the aristocracy practiced against the environment thrown back at the aristocracy as represented through the Green Knights' deadly game against Gawain. In the Green Knight's case, the trick of his beheading - the magic set by Morgana that allows him to survive the loss of his capital member - eliminates the risk of personal injury, putting him at an unfair position above his competitor, Gawain, in the exchange of blows. For the Green Knight, his play is on an even deeper level. Martin writes,

In its most extreme form, the playspace is utterly depoliticized and dehistorized. This is the Green Knight's level of play. Happy to fight and indifferent to injury, he consistently ignores the impositions of concrete reality. (Martin 313)

While courtly duels could elude political consequence, there were of course personal risks of injury. Losing could result in a fatal wound or the simple embarrassment of defeat in a warrior culture where reputation equated to social capital. Since he is an unknown knight, the Green Knight risks less social capital than Gawain, who could shame himself in front of his own court.

The ultimate game that Gawain must play will have nothing to do with violence, but rather his ability to follow the "strict code of behavior meant to restrain and refine his aggression," which is also an expression of chivalry, a side that we will find is underdeveloped in Gawain and possibly a key to undermining toxic masculinity today (312). With the decline of the 
feudal system and the rise of centralized power in the nation-state, aristocratic violence became a less reliable way of making a living. Crusades supplemented the scarcity of local war, but eventually, the relative peace in Europe during the Renaissance along with technological innovation and the mercantile economy caught up to the iron-laden warrior class. We could draw a parallel here to Bell and Braun's analysis of coal country; just as coal miners face the decline of the industry today, so too did knights gradually lose their raison d'etre to the changing times. Definitions of masculinity adapt to the needs of the era, and one such change is the moral reframing of violence.

Part of the honor of a noble lay in his holdings, which are presumed winnings from successful conquests - and a gallant knight should have many successful conquests. When the surplus of war and governance becomes commodified as a display of power, and there is no greater power policing the aristocracy, the door is opened to gluttonous exploitation. The opening of $S G G K$ does not spare its readers any descriptions of the holiday feast's opulence. Camelot's Christmas festival lasts fifteen whole days, the final meal commenced by "a flaring crack of trumpets," "all hung with bright banners," in accompaniment with bagpipes and drums (SGGK 166-67). On New Years, the courtiers seem a caricature of a medieval-ized Scrooge McDuck throwing money out of a skyscraper window, as “nobles ran / With New Year's presents in their hands, noisily / Passing in a crowd, calling "Presents!" (65-67). The king's table is "fringed with silk," and the castle hall is decorated with " velvet / Carpets, embroidered rugs, studded / With jewels as rich as an emperor's ransom" (76, 77-79). The narrator details the meal with similar excess.

Rare and delicate dishes were served, And venison in great slabs, and so many platters 
That there was almost no place to set them in front of

The guests, broths and stews in overflowing

\begin{abstract}
Abundance (121-5)
The passage continues to expound on the diet and drink of the courtiers for several more lines, but never does the poet venture to identify the source of this sustenance, and although readers can assume that servants and serfs are responsible for its production, they are only directly mentioned hoisting up the Green Knight's axe (478). They are also indirectly referenced in a simile describing the Green Knight's haughty disregard for Arthur, "as if the King were a waiter carrying / wine" (337-38). Servants are also mentioned by metonymy with their musical instruments, as we can assume someone who is not seated at the feast table is playing them. By erasing the processes of exploitation involved in the procurement of the many treasures and foods that make up the grandeur of Arthur's Christmas feast, the medieval aristocracy can remain ignorant of and separate from the sufferings of the exploited. Later in the poem, at the tables set in castle Hautdesert, the poet gives the reader gruesome detail of where 'the day's catch' originates, as the hunting scenes illustrate the violence perpetrated against the non-human so that Bercilak's court may have the same luxurious dinner. Surplus-as-status remains an indicator of personal achievement, and success in the highly economic venture of selfdetermination is depicted as the ambitious struggle of a rugged individual. This struggle of assertion, hailing from a medieval expression of power, becomes an unacknowledged war against the non-human. Today's conspicuous consumerism is partly a toxic masculine vestige that sanctions the United States' disproportionate consumption of natural resources, just as it sanctioned aristocratic domination of the people, animals, plants, and lands under fiefdom.
\end{abstract}


The omission of the servants also points to the attention paid by feudal society toward the adherence of the social hierarchy and the importance of one's position within it. The poet gives a peculiar focus to the seating arrangement of the table; proximity indicated loyalty and favor, a literal spatial projection of the hierarchy. Those nearest to the King maintained the greatest political influence. The Queen, Gawain, and select others sit around Arthur, "high in luxury / And around them lesser knights in rows.” (114-15). Since King Arthur's court is the greatest in the land, he hosts "The most famous warriors of Christ our King, / And the loveliest ladies in the world", but the courtly generosity of King Arthur also requires him to entertain any courtly guest that appears, even if the guest happens be a giant Green Knight come brandishing an axe (51-52). The Queen also exemplifies the restrictive gender roles employed to maintain the feudal system. At the table, Gawain and Agravaine, Arthur's nephews, are seated next to Guinevere on either side, illustrating their status as royalty via proximity to the queen. The poet then dedicates a separate quatrain to the description of Guinevere's beauty. She is "As beautiful a lady / As a man could have seen," but this excerpt hardly separates her from the surrounding decorations. If anything, she is Camelot's best table ornament; in fact, she does not have a single line of dialogue in the entirety of the poem. The importance of position, both physically and politically in these passages, communicates the high level of performance necessary to maintain these elaborate displays of hegemonic power. Hierarchy sanctions the actions of the patriarchal aristocratic class by relegating everything below or outside of the hierarchy as inhuman, and thus outside of the moral framework. The externalization of responsibility and the erasure of agency in the lower classes and the non-human permit the aristocracy to remove itself from guilt, and thus construct its aristocratic, anthropocentric courtly universe, represented in the arrangement of Camelot at feast. 
Some may credit Christian theology for establishing and perpetuating an anthropocentric worldview that frames everything non-human as subservient to human interests, and it would be simple to do so when reading a text as Christian as $S G G K$. Veritably, the religious group containing the greatest percentage of climate change deniers in the United States is white evangelicals (Funk \& Alper 36); however, this oversimplifies both Christianity and the Bible as a monolithically interpretable text. While the Bible certainly privileges humans as the only creatures made in God's image, the only creatures mentioned to have redeemable souls, it is simply unproductive to blame the world's most common religion for every environmental sin ever committed in the West. Interpretations of the Bible have changed over time, and readings have always altered to match the political and social needs of the era. Keith Thomas states that Tudor and Stuart interpretations of the creation account were informed by Greek philosophers, like Aristotle, who insisted that all things served a purpose, which was "to serve man's interest" (Thomas 17). Thomas points out that the greatest contributing factor to the voraciousness with which the West began to consume natural resources was the birth "of private property and a money economy, which led Christians to exploit the natural world" (23). Also, historians have found that some of the first arguments in the West to call for greater compassion to be shown to animals were Biblical ones, such as those written by St. Thomas Aquinas, who was concerned that "through being cruel to animals one becomes cruel to human beings" (Aquinas qtd. in Thomas 151). Richard Hoffman, in his book, An Environmental History of Medieval Europe, points out that "The best Christians, all agreed, were those monks and nuns who sought to withdraw from the material world, to control their material bodies, and to propel their souls towards union with the spiritual nature of God" (Hoffman 92). Indeed, Corinne Saunders, , in The Forest of Medieval Romance: Avernus, Broceliande, Arden, details the ways that the 
woodland wilderness of romance borrows heavily from Biblical accounts of the desert; although it often served as a place of temptation, the Biblical wilderness also brought solitude and spiritual revelation, as seen in the wanderings of the Jewish people, Jesus' forty days, or John the Baptist's ascetic lifestyle (10-14). Furthermore, the 'steward of creation' argument, which cites Adam's role, assigned by God, in properly managing the Garden of Eden, extended to all creation, remains a popular view today. There are numerous of faith-based environmental organizations engaged in contemporary political work and environmental justice activism. In Kentucky, one could look to the role the Sisters of Loretta played in shutting down the Bluegrass Pipeline project, or the continual efforts of Kentucky Interfaith Power and Light in organizing and lobbying for clean energy legislation. At a much larger scale, the Catholic Church has adopted a strong position in favor of addressing the environmental issues of today in Pope Francis' second encyclical, Laudato si'. Throughout the encyclical, Pope Francis repeatedly blames the arrogance of man and modern industrialized, technocratic society for abusing the Earth. He writes, "We have come to see ourselves as her lords and masters, entitled to plunder her at will... We have forgotten that we ourselves are dust of the earth," echoing Leopold's condemnation of the conqueror mindset (Francis 2). Consider the following passage from Laudato si.

We are not God. The earth was here before us and it has been given to us. This allows us to respond to the charge that Judaeo-Christian thinking, on the basis of the Genesis account which grants man "dominion" over the earth (cf. Gen 1:28), has encouraged the unbridled exploitation of nature by painting him as domineering and destructive by nature. This is not a correct interpretation of the Bible as understood by the Church. Although it is true that we Christians have at times incorrectly interpreted the Scriptures, 
nowadays we must forcefully reject the notion that our being created in God's image and given dominion over the earth justifies absolute domination over other creatures. (Francis 67)

To summarize, with its bubbled gaiety, Arthur's Christmas celebration at Camelot exemplifies the way a privileged society omits its environmental sins so that it may purely enjoy the spoils of its exploitative practices. Violence enforces the structures of exploitation; possession categorizes the world into resources to be harvested, subservient to human purposes; and hierarchy establishes man - and man alone - as separate and righteously superior to nonhuman nature, with firm boundaries excluding anything else as outside of moral consideration; these tenets constitute the framework that allows the privileged military class to exercise its patriarchal dominance over nature and the lower classes. The atmosphere is pierced, however, with the Green Knight's entrance. Through his games, he not only foreshadows the contradictions of chivalry, and thus the decline of the court, but also throws the court's environmental sin in front of them, epitomized in Gawain's bloody beheading of the Green Knight, which causes the court to drop its merriment in a moment of horror. Martin interprets it as a violent reversal of chivalry itself. "Forgoing all their courtly poise, the horrified lords and ladies react with violence of their own by kicking the severed head away from them" (Martin 313). Violence is the knee-jerk reaction because it is the way the hegemony has always maintained its power; also, there is the need to vehemently deny the reality in front of the court in order to defend its worldview, and this should strike the reader with a degree of familiarity, considering the politics of climate change. As Gillian Rudd writes in, Greenery: Ecocritical Readings of Late Medieval English Literature, "it seems that in order to be comprehensible and so command any respect, the non-human world must take on some kind of human guise," (122). 
The anthropocentric chivalric world will only acknowledge the agency of the non-human realm when it is anthropomorphized, and only in a way that others it as a supernatural or alien force. Gawain and Arthur are impressed with the visitor, and so they laugh off the spectacle with good spirit. Despite having suffered embarrassment at the Green Knight's disturbance, the courtly cheer restores when the Green Knight leaves "because the sacrosanct, autonomous playspace of the court requires the elision and suppression of extraneous political considerations" (Martin 314). Should the court have to seriously consider the ramifications of a brewing conflict with what appears to be a warrior of the wild, possibly nature itself, the knights of Camelot would be faced with the decision to either address whatever offense they had made against the Green Knight's unknown faction and appease them, or they would have to make war. If the Green Knight truly is a representative of the non-human realm, then the overbearing threat of famine, disease, and natural disaster - which were all gruesome realities in the late fourteenth century would bring the knights to recognize the need to take political action, either negotiating a compromise or seeking a greater power to aid them. They might even need to permanently restructure the social order to appease the non-human threat. However, since the game is depoliticized, and only a supposedly friendly contest between Gawain and the Green Knight, the court is able to dismiss the disruption as another marvel. They hang the Green Knight's axe "high against / A tapestry, a trophy for everyone to stare at" (SGGK 478-79). Having driven off their guest head in hand to the mysterious beyond, the court re-establishes its island of chivalric order, a premature triumph over the non-human. Hidden under the largesse of the court, the foreboding lines of the end of Part One betray the inner terror of Gawain at the threat of the Green Knight and his challenge; this murmur extends to all of Camelot's panic at the perceived intrusion of the non-human. 
And now, Gawain: think.

Danger is yours to overcome

And this game brings you

Danger. Can the game be won? (SGGK 487-90)

Denialism is a necessary tool for any oppressive institution to maintain power. By dismissing opposition as irrelevant or untrue, one can validate any idea or practice without having to support its veracity. When the Green Knight comes under the guise of a courtly game appropriate to the spirit of the Christmas season, Arthur and his Knights unwittingly invite a real political threat, a powerful critique of the Knights of the Round and their brand of chivalry. The greatest threat to the court is the abolishment of the rigid social structures that afforded the aristocracy its power, and the separation of human and non-human is the most important boundary. As long as the nonhuman can be categorized as wilderness, outside of the human realm, it can be exploited with limited ethical concern. Gillian Rudd writes,

If we value the wilderness for its standing as an untouched, regenerating force, we are also wary of too much direct contact with it... Humans have a vested interest in believing in such indestructibility, since it relieves us of both anxiety and responsibility (Rudd 125) In his groundbreaking essay, “The Trouble with Wilderness," Bill Cronon illustrates how modern attitudes toward nature, especially those of conservation environmentalists, still fall back on the nature/civilization divide. Whereas in the medieval era the wilderness was a harrowing place of madness, and civilization was the righteous place of man and society, post-Romanticism attitudes in the modern world have posited the wilderness as a retreat from the pollution and desolation of urban life. The problems of such strict categorizations impede the formulation of practical solutions for the numerous environmental problems we face today. As Cronon states in 
the following passage, if humanity cannot conceive of a marriageable union between this human/non-human binary, then we will doom ourselves to ecological mismanagement.

This, then, is the central paradox: wilderness embodies a dualistic vision in which the human is entirely outside the natural. If we allow ourselves to believe that nature, to be true, must also be wild, then our very presence in nature represents its fall. The place where we are is the place where nature is not. If this is so-if by definition wilderness leaves no place for human beings, save perhaps as contemplative sojourners enjoying their leisurely reverie in God's natural cathedral — then also by definition it can offer no solution to the environmental and other problems that confront us. To the extent that we celebrate wilderness as the measure with which we judge civilization, we reproduce the dualism that sets humanity and nature at opposite poles. We thereby leave ourselves little hope of discovering what an ethical, sustainable, honorable human place in nature might actually look like. (Cronon 11)

The significance of Cronon's wilderness critique to this discussion is that, while we must acknowledge that the view of all wild as a natural resource is an extension of the human/nature binary, it is not the only result of that system of classification. Another logical outcome, as Cronon observes, is the view that the human and non-human will always find each other at conflicting ends. While the preservation of undeveloped land is crucial to the health of the physical world, we mistakenly assume that all the important non-human processes and cycles that maintain the planet occur outside of our civilized spaces; however, the air, soil, and water of this planet permeates in every city, every backyard, and every farm. We might imagine that what we throw or flush away vanishes, or that electricity, meat, and vegetables come from an endless wellspring, but the reality is that the daily functions of first-world living require an enormous 
load of resources and create an equally terrifying amount of waste that may come to affect the quality of that shared air, soil, and water, reminding us environmental protection is not an animal rights issue; it is a public health issue. "Any way of looking at nature that encourages us to believe we are separate from nature - as wilderness tends to do — is likely to reinforce environmentally irresponsible behavior" (17).

In interpreting $S G G K$, readers must recognize that the Green Knight is not simply nature made human, but that his most prominent characteristic is the ability to exist between these binaries. The Green Knight, with his seemingly dissonant shifts in identity and classification, challenges the patriarchal anthropocentricism dominating the social milieu of feudal society. The Green Knight signals the greater individual freedom of modernity, demonstrating that certain toxic masculine behaviors and chivalric conventions no longer apply in the new context of citizenship. In "Ecology," Carolyn Dinshaw compares the Green Knight to the leaf head relief sculptures found in medieval churches and other historical sites throughout England and Western Europe. These leaf head figures are unnerving, surreal characters enmeshed in foliage and nature imagery so that one cannot tell if the figure is human consumed by wild, wild absorbed by human, or some other hybrid of being. The Green Knight, like the leaf head, provides a challenge to the assumed anthropocentric boundaries between human and non-human in the way its human and vegetative elements are inseparable from the other; Dinshaw argues that the leaf heads show Europeans were thinking about the relationship between human and non-human, "dominance and subjection, about hierarchies" well before the "humanism' of modernity" (Dinshaw 354).

It hints at a creaturely way of being that refuses hierarchy - the way the foliate heads do. These chivalric body parts do not add up to an orderly and ordered whole in a vertical hierarchy of creation. Instead they are connected with one another horizontally, so to 
speak: detachable head trailing by the hair, borne by hand and arm issuing from this ugly trunk on horseback, gallops away to parts unknown. (Dinshaw 357)

The Green Knight, who looms over the poem with such a mystery that the poem dedicates half of its title to him, more than figuratively embodies the central question of the relationship between human and the natural. His overwhelming greenery, with the green hair, green horse, green clothes, and green skin - "As green as grass, or greener! And glow / Brighter than emerald enamel and gold" ( $S G G K$ 235-36) - elicits from the reader an assumption drawing from the firm association between the color green and nature; however, Rudd explains in "Being Green in Late Medieval English Literature" that the color had different connotations that no longer exist today. During medieval times, green was associated with "the color of the natural world" but also the color of "falsehood, unreliability, and deception" (Rudd 30). A contrast can be made in the opposite color blue, which then represented faithfulness and constancy, and Rudd points out that Gawain indeed dons a blue robe in Part Three while staying at Bercilak's castle (36). The implication of the color binary not only emphasizes the conflict between Gawain and the Green Knight, but also solidifies the Green Knight as a figure that sparks change. The color green may be the devil's color - a reading that hints at the threat of paganism lurking in the poem - the Green Knight is less antagonistic than that; he embodies ambiguity, paradox, and change (36). The monstrosity of the Green Knight is certainly his seeming ability to elude death; the subtext of Camelot's fear of the Green Knight is his perceived ability to thrive, even outcompete the Knights of the Round at court, as a rogue outside of their stiff hierarchy. The Green Knight leaves telling Gawain to search out his suspicious Green Chapel, frustrating the court's attempts to classify him and his political allegiance. His individualism - the private assemblage of his perhaps dissonant factional ties, part man, and part monster - is a clear threat to the strict 
hierarchical feudal structure that keeps the court in power. What's most baffling to the denizens of Camelot is the absolute politeness with which he sabotages their party. Although he appears to have bloomed out of the most fertile brush, he is as courtly a knight as any other.

Readers easily recognize the Green Knight's connection to the natural world, but they may fail to notice how the poem emphasizes his knightly masculinity as much as his otherworldly greenness. He holds "a branch of holly in one hand," but also "an axe in the other" (SGGK 206, 208). He bursts into King Arthur's Christmas celebration, "the biggest creature in the world," his waist is "flat," and his chest is described as "grim and immense," along with a "fine and elegant" countenance of "easy grace" (141-46). He comes richly dressed, albeit entirely in green attire. His wear is edged with "white ermine," his stockings are "embroidered silk, / And his shining spurs were gold," and his steed is just as carefully adorned $(155,158-59)$. The Green Knight intimately knows the courtly rules of conduct, as evidenced by his ability to flaunt the normal conventions of behavior, laughing as he teases Arthur and his court. Rudd points out one such play on protocol when the Green Knight twice refuses to offer his name to Gawain after Gawain had given his - first, when it is implied that Gawain's strike will kill the Green Knight so that the return stroke wouldn't be necessary, and second when, instead of his name, the Green Knight offers only the dubious advice to seek out his green chapel (Rudd 114). The Green Knight finally gives his name to Gawain as a gesture of camaraderie after the exchange of blows is complete. The Green Knight is able to have his fun because he knows that his challenge, in combination with his leafy appearance, is unduly suspect and a mockery of the norm. Additionally, the Green Knight knows that the court is honor-bound to accept any challenge to preserve the reputation of the court, which is, in the Green Knight's own teasing words, "praised so widely - the proudest, / The boldest soldiers to sit on a horse, / The bravest and best of men" (SGGK 259-61). Martin 
notes that the taunting of the Green Knight is so effective that King Arthur misinterprets his intentions, reacting with the aggressive - and rather discourteous - threat of violence, telling the Green Knight "If you've come to fight / We'll fight and not run, sir" (Martin 312, SGGK 27879). Of the Green Knight's chivalric prowess, Martin goes on to say that he is "A blend of the amicable and the quarrelsome, the crude and civilized, he is a kind of monster, but he embodies the monstrosity of the militarized society that produced him," which makes the Green Knight, as a reflection of the extremes of chivalry, the perfect entity to reveal the vulnerabilities of the patriarchal aristocracy (Martin 311).

By the end of $S G G K$ we know full well how knightly the Green Knight is - he reveals himself to be none other than the lord of castle Hautdesert, Sir Bercilak. As Bercilak, he overturns many of the assumptions the Green Knight's grand entrance would lead readers to make, and he proves to be part and practitioner of many of the same toxic masculine behaviors that rule the customs of Arthur's court. The foremost example of his toxic masculine behavior manifests in his hunting pastime. $S G G K$ provides an exquisitely detailed account of the three chases taken on by Bercilak and his men - hundreds of lines even - while Gawain and Lady Bercilak have a cat and mouse game of their own in the castle. Scholars have long written on the connections between the hunting and bedroom scenes, and most draw on the hunts as a metaphor for Lady Bercilak's sexual predation of Gawain. In his 1928 essay, "The Significance of the Hunting Scenes in Sir Gawain and the Green Knight", critic Henry Savage illustrates how the species of game animal procured in each of Bercilak's outings parallels Gawain's moral standing as the exchange of winnings game progresses; during the first two days, Gawain behaves appropriately to courtly norms, and so Bercilak secures two noble species of animal, boar and deer. On the third day, Bercilak slays a fox, a sly vermin animal, to signify Gawain's subsequent 
deceit in taking Lady Bercilak's green girdle and withholding it from Bercilak (Savage 5). From an ecocritical perspective, one could read the parallel hunting and bedroom scenes as a condemnation of Bercilak's hunts as a sinful act weighted equally with the seduction and deceit happening in the bedroom. The excessive violence of Bercilak's practice is established in the first hunt, where Bercilak and his retinue of "a hundred wonderful hunters" and their dogs massacre so many deer that "no one could count them" $(S G G K 1144,1322)$.

... they drove does deeper

Into valleys, and arrows slanted down,

Great broad arrows flying at every

Turn, cutting deep in brown hides.

Hah! They screamed, and bled, and high

On slopes they died, hounds hurrying

After them, and hunters with horns, blowing

So hard that the echo seemed to crack

Cliffs. And deer that escaped arrows

Were caught by keepers, cut down and killed,

Hunted back from safety of high ground (1159-69)

The method of hunting described in the above excerpt is known as the "deer drive," or "bowand-stable" hunting, a technique of where hunters used clamorous sounds and dogs to round up and channel large herds of deer towards kill stations so that nobles could pick them off with relative ease (Twomey 47, Aberth 189). The historical use of this technique was limited to royalty; only the king could pool the resources necessary for these hunts. In addition to the royal foresters who policed the king's hunting parks, the crown also employed about seven full-time 
hunters in order to acquire the amount of meat necessary for the crown's many royal gatherings, especially during the Christmas season, when the hunters were expected to secure hundreds of game animals within a short time frame (Aberth 187). Some nobles hired hunters on a part-time basis, but nothing compared to the assets of the royal huntsmen, who had as many as fifty hunting dogs and could always hire additional help (187-88). The deer drive made large yields of venison possible in a short amount of time. In "The Ways and Words of the Hunt: Notes on 'Sir Gawain and the Green Knight,' 'the Master of Game,' 'Sir Tristrem, Pearl,' and 'Saint Erkenwald," Ad Putter draws attention to the social distinctions between the hunter and the noble that manifest in the procedure of the deer drive.

... the hunters in a deer drive fall into two distinct groups, which are clearly distinguished by status. On the one hand, there are the nobles, who choose their spot in the forest, ready to shoot any animals that come their way, with hounds and horses at hand to track any wounded deer. On the other hand, there are the huntsmen, who must flush out the animals and drive them on towards the archers.... (Putter 357)

In $S G G K$, the division in status between Bercilak and his hunters is more readily apparent during the boar chase. In this scene, the hunting party corners the victim into a hollow after wearing it down with nipping dogs and arrows, but saves the killing blow for Bercilak. More accurately, it is inferred Bercilak is the only one capable of dispatching the "beast" who freezes the other hunters with "fear / of being torn" by its tusks; the animal's "hooves pawed / At the ground, foam grimaced on his snout" ( $S G G K$ 1571-89). The subsequent duel between Bercilak and the boar is glorified into an epic battle as opposed to its reality, which is the cruel execution of a cornered, injured animal. In "The Hunting Scenes in 'Sir Gawain and the Green Knight', J. D. Burnley comments that the boar chase's mirroring of the one on one duel "reinforces the implicit 
associations which the animal has with evil and gives [the reader] a sense of relief at safe deliverance" (Burnley 9). Amidst the audience of his hunters, Bercilak coolly steps off his horse, draws his blade in front of the boar, then approaches it in its seeming-lair.

And the boar saw him, saw his bright sword,

And his hackles rose, and he sorted so loud

That the hunters were afraid for their lord's life.

Then the beast rushed out at him, straight and quick,

And man and boar blended in steaming

White water; but the boar had the worst, for the lord

Had measured his charge, and aimed his sword

Into his throat, and planted it deep,

Down to the hilt, so the heart was cut,

And snarling as he fell the boar surrendered

And dropped. (SGGK 1586-96)

While the boar is described as somehow both savage animal and worthy adversary - by comparison, would one consider a half dead knight an honorable opponent? - Bercilak comes out as a cool-headed and capable warrior. His single deadly strike requires both boldness and precision, reflecting his battle prowess, and ultimately, his victory over the forces of non-human nature, simultaneously asserting himself as the premiere human, the bravest man among the hunting party. It is an assertion of his place at the apex of Hautdesert's social and trophic hierarchy. The boar's rabid characterization deems it unfit for empathy inside the moral framework of chivalry. As an object of sport, it is unworthy of "pity, / Greatest of knightly virtues" (653-54). 
After each chase, $S G G K$ delves into the process of butchering the day's quarry with same detail it dedicates to the hunts themselves. The pitiable boar has its intestines removed, body split down the spine, and its head vaunted on a pole. The deer carcasses are amassed in a pile and distributed, with the "noblest knights" choosing their pick first (1325). This award system is another practice that emphasizes the hierarchical structure of courtly society, even in the court of the subversive Green Knight.

Then they ran a hole through the ribs and hung

The carcasses by the hind legs, each

Taking the parts proper to his rank. (SGGK 1356-59)

Romance basks in hyperbole, and $S G G K$ is no exception. Gawain praises the deer drive's yield as "the best / Game [he has] seen in seven winters" (1382-3). Revisiting the motif of abundance from Arthur's Christmas feast, Michael Twomey, in "How Green was the Green Knight? Forest Ecology at Hautdesert," points out that "every aspect of the medieval forest was commodified... even without taking into account Fitt II's exchange of winnings" (39). Toxic masculinity, seeking to express its dominance, relegates all the organisms and ecological systems of the forest into manageable and exploitable game - forms of property and possession. The bounty of meat becomes a display of wealth in Bercilak's hall; yet, the whole of the hunting spectacle in $S G G K$ is quite different from the hunting practices found in historical reality. As Aberth writes, representations of hunting procedure found in medieval romance texts fail to match up to archaeological findings and historical game records.

... the picture we get of hunting from the manuals, romances, and tapestries is a highly ritualized and ceremonial one... whose main value seems to be that it reflects the cultural attitudes and image that the aristocracy preferred to project of itself, rather than showing us 
how hunting was actually practiced in real life. In keeping with this, the manuals and other stylized depictions of medieval hunting emphasize hierarchical dominance of the aristocracy over both their social inferiors among humans and over the natural world of animals. (Aberth 195)

Saunders writes that the technical and ceremonial complexity of the hunt marks the civility of the act, as it forms part of the "training of knighthood"; however, she also notes that the violence of the hunt in $S G G K$ contradicts that very notion of its civility, reflecting the paradoxical chivalric dilemmas Gawain must resolve to overcome the exchange games (152). At Hautdesert, it is impossible to know who is civilized and who is wild, as she writes,

The descriptions emphasize the peculiarly violent nature of the hunt despite its atmosphere of ritual, beauty, and festivity. Here, the savagery and excess of Bertilak's apparently courtly pastime perhaps echo the wildness and violence which underlie the Faery Hunt in Sir Orfeo (153)

Consider carefully in this excerpt who Saunders identifies as savage. It is surely not courtly society, which practices such barbaric ritual violence to assert its dominance; but neither is it the non-human, which, although barred from civility by definition, is victimized by the human. The patriarchy's civility is based on its superiority to nature, but it can only assert that dominance by performing the same acts of barbarism that it attributes to the very wildness it wishes to overcome. Bercilak, through these hunting scenes, is characterized as a rugged outdoorsman, which is type of masculine display of mastery over nature. While the Green Knight appears to be a member of nature, Bercilak is revealed to be another one of its conquerors; perhaps this characterization is the poet's manner of connecting Bercilak to nature in the only way a noble in 
the fourteenth century is supposed to relate to anything; that is, a relationship of master and subordinate.

While nobles may have orchestrated these kinds of highly coordinated hunts with ritual dismemberment akin to those in $S G G K$ in the High and Late Medieval Periods, though the physical evidence is inconclusive, Aberth states that these ceremonialized hunts were likely rare occasions limited to royalty, probably "as common as a coronation"; records show only three such great hunts between Henry III in 1248 and 1255, and Edward II in 1323 (196-97). In comparison, peasant hunters dispensed with all ceremony save that of hiding carcasses in order to evade the enforcement officials of the royal forest; they hunted with such opportunism as to sometimes scavenge "the carcasses of deer wounded by other hunters or even ones diseased and half-eaten by wolves and dogs," the necessity of which paints a grim picture of life in the lower class during these periods (Aberth 197, 187). The royal forests and parks of Britain were playgrounds and income sources for the crown and the nobility, so a number of regulatory protections went into their maintenance. Penalties for poaching in the royal forests were severe, and abuses were common.

Fines for the hardened offender could run into the hundreds of pounds, and merely to be caught in the vicinity of a dead deer could result in years of imprisonment while some notorious poachers were arbitrarily beheaded or shot to death by their pursuers (Aberth 191)

The history of England's forests is rife with struggle over land use among the crown, the nobility, and the lower classes; while the aristocracy saw the woods as a wilderness hunting ground and economic wellspring, the peasantry found in these lands their home and means of survival, especially those who relied on timber, farming, and pasturing for their livelihoods. "For 
them, the forest was not simply a romantic idea, but a vital landscape without which life would be scarcely possible" (Aberth 139). The Charter of the Forest, which established the legal basis and administrative framework of the royal forests, became a frequent target of barons after 1217 - or "any group that wished to limit the power of the king," for that matter - and was tied closely with the Magna Carta and the issues it represented (Young 135). "Forest" did not just mean woodland, but referred to an assortment of human-engineered habitats under protection of forest law, as the overwhelming majority of England's virgin land and forests had already been altered by human activity (Thomas 201, Aberth 111). Afforestation referred to the process of placing land under forest law, and disafforestation, not to be confused with deforestation, referred to the process of removing land from the protection of forest law. Reforms in the beginning of the fourteenth century spiked disafforestation, increasing private and common land ownings across England. Aberth states that, by 1334, as much as a third of royal forest lands were disafforested from the prior hundred years (121). To put this in perspective, possibly a quarter of England was afforested in the thirteenth century (Thomas 200). In the later fourteenth century, tales of Robin Hood emerged, a tale squarely concerned with the draconian policing of the royal forests, despite the fact that it had long become a resolved issue (Aberth 121). Without the protection of the royal forest law, woodlands became subject to the Tragedy of the Commons, and timber sales from mature trees like oak were so profitable that only the Black Death could temporarily halt the industry's machinations (123).

Twomey accurately identifies the woods of Hautdesert as a private hunting park, much opposed to Gawain's perceived wilderness, and that such a park was "chiefly a response to disafforestation... by which agricultural and economic encroachment nibbled away at the woodlands" $(41-45,51)$. Following successive waves of the Black Death, some hunting parks 
were expanded, while others went to the economically oriented commons, and Bercilak's park possibly reflects this reality (51). As Thomas describes, two hundred years later, "In the sixteenth and seventeenth century many of these reserves were disparked or given over to cattle, as an expanding market provided incentives for the more profitable use of the land" (Thomas 202).

In a sense, emparking was a desperate attempt to preserve ancient woodland flora and fauna, and the way of life they represented. As John Langton... puts it, 'The procedures of disafforestment, enclosure, and systematic land management to supply timber and food crops epitomised the coming of modernity as perfectly as the forests themselves had exemplified feudalism.’ Parks became an expensive and unprofitable luxury that only the wealthiest could afford. (Twomey 51)

Just as Gawain's anxiety at the mercy of the Green Knight is a signifier of aristocratic anxiety in the Late Medieval Period, so too is Bercilak's anachronistic hunting ground. "It seems significant that every aspect of the forest represented in $S G G K$ is related to the chase. Nowhere does Bercilak overrun a sheep pasture, a tenant's fields or a village in his demesne" (Twomey 53). The omission of more practical terrains, such as assarts or agistments, could entertain two possibilities. The first, and most likely, is that the poet is unconcerned with the affairs of peasants, and the descriptions of Arthur's Christmas feast have confirmed as much already. Just as the hunting manuals and romance texts Aberth mentions reflect an image of the nobility that the aristocracy prefers to disseminate, so too does $S G G K$ touch on a nostalgia for a time when wilderness dominated the English landscape, and when knights campaigned across the countryside - in other words, a time when the aristocracy believed they held greater power. The second possibility is that Hautdesert lacks these facilities and will soon crumble due to bad 
management and lack of provisions - a deserving fate for any court that rivals the true royalty of Camelot. The likelihood of this scenario depends on the biography of the poet himself; as a probable landowner and educated noble, the poet could have definitely had the sophistications of land management under his belt. The poem's most encompassing 'bird's eye view' of the castle given towards the end of Part Two mentions "lawns" and "grass / And grounds running more than two miles," yet it is uncertain if these are pastures for livestock or grasslands to attract game animals (SGGK 768-70).

Twomey argues that Bercilak could be thought of as an effective land manager, and points to the poem's specific mentioning of the proper hunting season in line 1156, and the suggested practices of pollarding and coppicing in line 874 to support his claim (Twomey 45). Coppicing involves cutting a woody plant to the stump to encourage sprout growth low to the ground, while pollarding involves hacking the trunk of a tree high so that new growth evades the reach of grazing animals (Hoffman 184-86). These practices increased the lumber productivity of the forest, especially for fuel purposes, without doing great long-term harm to the plant. Twomey observes that since charcoal is used for the fireplace in Bercilak's castle, he likely employs coppicing and other practices to effectively manage "a sustainable heterotopia... with far more biodiversity than medieval farms raising a limited number of crops" (Twomey 44). Ultimately, since its purpose was to provide game and timber, Bercilak's hunting park would bring ecological degradation to the woodlands. Species of animals and plants without economic value and considered vermin, such as the fox, were culled despite their ecological value, and frequent disturbance of the woods from coppicing and pollarding compacted the soil and prevented mature tree growth, as well as eradicating tree species that cannot survive multiple rounds of these procedures (Twomey 50, Hoffman 186). Since its principle aim is to flatter the nobility's 
sense of superiority, Bercilak's sport is an exercise in toxic masculinity, and its parallel with the bedroom seduction scenes reflects the danger Gawain faces at Hautdesert as a reversal of the same systems of oppression that he and his class have utilized to maintain their power.

Bercilak's status as a noble entails certain ramifications considering his allegiance to Morgana Le Fay. The moment Morgana's presence is unveiled to Gawain and the reader, the central conflict of the plot becomes definitively anthropocentric, as the questions of nature and the Green Knight fade to the rivalry between Morgana and Arthur (Rudd 112). While Morgana certainly emanates an aura of pagan mystique, the whole complicated arrangement of marvels and trials turns out to be subservient to the purposes of shaming Arthur's court and threatening his lover, Guinevere. Almost disappointingly, it is all a prank inspired by Morgana's incestuous lust and jealousy. Bercilak tells Gawain, Morgana sent me to your king's castle, To test your pride, to determine the truth Of the Round Table's fame, and the tales that tell it.

She hoped my lopped-off head would addle

Your brains, would frighten Arthur's queen

And kill her with fear, (SGGK 2456-61)

Rudd describes the plot of $S G G K$ as a progression of the presence of the non-human world being absorbed and replaced with the concerns of the human one, just as the Green Knight is assimilated into Bercilak and the uncivilized wilderness of Wirral subsumes into Hautdesert and the politics of two competing courts (Rudd 112). More so, the elaborate scheme reveals itself as a ploy to shame Arthur's Knights of the Round and bring Gawain over to Morgana's court; in fact, Bercilak asks Gawain twice after finishing the exchange of blows to rejoin him at 
Hautdesert. The Green Knight's insults, even as he prepares to bring his axe down on Gawain, all pertain to his membership to the Round Table. "Let Arthur's knighthood save your neck," he jokes in line 2297. Gawain returns to Camelot because accepting Hautdesert's female leadership would amount to the ultimate blow to the social order that protects Gawain's privileged status. Misogyny unveils itself as a driving factor of Gawain's chivalry when he blames his dishonesty as just another casualty in the long history of women dragging men to moral failure. He cites the biblical examples of Adam and Eve, Solomon the Wise, Samson and Delilah, as well as David and Bathsheba. He says,

And these were the noblest knights of their time,

The best, the very best, who walked

The world

In those days - and women tied them

In knots, whirled them

In circles. I've been beguiled,

As they were: this excuse should be heard. (SGGK 2422-28)

It is not surprising then that Gawain refuses to return to Hautdesert and make good on Bercilak's offer to "make [Lady Bercilak] your friend, who was once / Your bitter foe," because women remain Gawain's enemy ( $S G G K$ 2405-06). He is satisfied to sit next to Guinevere at Arthur's Round Table for the political benefit of being closer to Arthur, but he dismisses the idea of another meeting with the woman who bested him. Gawain makes perfectly clear what the only appropriate role for a woman is under the feudal patriarchy when he says of women, "how wonderful if men / Could love them well, but never believe them!"' $S G G K$ 2421). Awkwardly enough, he says this before Bercilak reveals his allegiance to Morgana, even referring to her as 
"Morgana the goddess," (2452). In the canon of SGGK, Morgana learned her magic from Merlin by seducing him (SGGK 2445-49). Ironically, Morgana's attack against Arthur's court is a rebellion of the very sexual oppression that Gawain prescribes.

That Sir Bercilak is simply another aristocrat guised in Morgana's witchcraft does not mean that $S G G K$ dismisses its questions about human-ecological relations, but instead suggests that it is, like Gawain, chivalry, and masculinity, in a work of transition. The poet does not have the ecological discourse that would later be available to writers like Leopold; the poet has the conventions of chivalric romance and the Biblical scripture. Bercilak's hunts point exactly to the source of aristocratic wealth - the domination and exploitation of land, animals, women, and the lower classes enforced through violence. Gawain is put in danger by those same means, forcing him to rethink his own understandings of proper chivalric behavior. Bercilak's play as the Green Knight and servitude to a female lord does nothing to hurt his reputability as a knight. It makes no threat to his masculinity, and this much is confirmed in Gawain's farewell to Bercilak. "They embraced, and kissed, and commended each other / To Christ" thus affirming their fraternal bond as fellow knights ( $S G G K$ 2472-73). If one were to construct a few binaries to establish the world order of the Gawain poem, we would find the Green Knight and Gawain juxtaposed as nonhuman and human, Morgana and Arthur present a female/male binary, as well as a Christian/pagan binary. Between Camelot and Hautdesert, located deeply past the forest of Wirral, we also entertain an anthropocentric divide between wilderness and civilization. From these binaries we find a hierarchy of the male, the Christian, and the civilized above the nonhuman, the pagan, the woman. Thanks to the Green Knight's double identity as Bercilak, he falls under the sphere of each of these factions, at one point or another. He is the courtier and huntsmen, patriarchal feudal lord of Hautdesert and vassal to a witch, chivalrous knight and 
pagan monster. Bercilak's fluidity of identity and self-removal from the apex of the courtly hierarchy challenges the rigidity of the patriarchal feudal hierarchy. Bercilak's mutability is not a contradiction or ruse, but a signal of the greater social mobility and individuality to come with modernity. The fact that the Green Knight has hidden from Gawain the true intentions of his trials up until the conclusion of $S G G K$ shows that he is an individual with a complex interior life, able to play the courteous host and undermine Arthur's court at the same time.

Across the poem of $S G G K$, we find characters with contrasting inner and outward emotions, such as Gawain's outward courtesy hushing his inner panic, or the Round Table's mournful gossip beneath its cheery sendoff for Gawain in lines 539 through 542. In "The Uses of Chivalry: 'Erec' and 'Gawain,", T. A. Shippey describes the performance that courtesy demands even in stressful situations. He writes,

The virtues of chivalry of course include those of the heart... but often bend quite markedly towards those of the face, 'largesse', for example, implying an element of parade not present in modern generosity. [Courtesy] can be considered in this way, and should also be linked with another 'superficial virtue' repeatedly expressed in Sir Gawain, 'blitheness' or 'good cheer'.

In the poem characters are often placed in unhappy or dangerous situations. But their response is nearly always the same, to deny, to cover up, to put a good face on it. (Shippey 247)

In $S G G K$ we see concealment employed by both courts at opposite political ends. Arthur's court, in the beginning of the poem, uses it to discredit the threat of the Green Knight, yet quietly mourns the premature loss of Gawain's life at the same time; chivalric courtesy is utilized as a tool of denialism. Morgana tasks Bercilak with undermining the pride of Arthur's court and he 
and his wife do so excellently. They successfully push Gawain to the limits of his courtesy and tempt him into taking the green girdle, and, as the Green Knight, Bercilak thoroughly humiliates Gawain for it. Bercilak's function in $S G G K$ as a noble subversive to Arthur's court manifests most clearly in his duties as a host, and the magnanimity he shows unto Gawain in Parts Two and Three proves to be a simulacrum to cover the subversion of Gawain's courtly ideal through the exchange games. Kathleen Palti, in "The Bound Earth In Patience and Other Middle English Poetry," connects the parallels between the hunting and bedroom scenes as a metaphysical representation of the way $S G G K$ presents the illusory separation of space; just as Gawain is blind to the connection between the exchange of prizes and the exchange of blows, so too is he unaware of the inseparability of the inner and outer worlds, both in terms of physical space as seen in the walls between the wild hunting forest and the human bedroom, and, more importantly, between the performance of courtesy and the execution of private morality exemplified in Gawain's coy acceptance of the green girdle (Palti 47-48). It demonstrates how private sins are never just that; in an ecological context, toxic behavior burdens everyone. One would not assume a hurricane to be anyone's private affair - so why is cumulative ecological sin treated so? People are encouraged to recycle and take shorter showers, but we hesitate as a nation to implement strong policy towards regulating environmental quality.

The subterfuge of the exchange games begins the moment that Gawain believes he has left the cold wilderness and entered a shelter of courtly society in Castle Hautdesert. As Rudd and Saunders observe, the castle appears as a miraculous answer to his prayer (Rudd 121, Saunders 150). Religion, Rudd finds, is understood by Gawain to be the divide between the human and the wild landscape that he journeys through to find the Green Chapel (Rudd 56). Passing through the Wirral Forest, the narration remarks that it is a place "where few men / 
Lived whom God or a good man can love" (SGGK 701-02). He passes through the Wirral "through dreary scenes," "in many strange lands," where he must brave the cold, "dragons," "wolves," "satyrs," "forest trolls," "bulls," bears," "boars," "giant ogres;" "enemies so foul and wild that they forced him to fight for his life" (SGGK 710-23). The settings of $S G G K$, scholars agree, is a fantastical mix of real world geography and the faerie realm of romance where anything can happen. "The medieval romance tradition," Aberth writes, "does not provide particularly realistic depictions of the forest, with the notable exception of $S G G K$, where the poem supplies detailed references to the local topography of North Wales" (Aberth 130). Rudd argues that the poem takes readers from identifiable ground in Logres, identifying markers like the Anglesay Islands and Holy Head, but once he enters "strange lands" past the Wirral, readers are thrown into the "archetypal forest of romance text: a place of personal trial, unexpected ambush, marauders, honest and dishonest men outlawed, hermits, and wild animals" (Rudd 5758). Gawain struggles through an inhospitable environment that seems to fundamentally oppose him.

And the fighting was hard, but the foul

Winter was worse, so cold that rain

Froze before it could fall to earth;

Sleeping in his armor, sleet came close

To killing him, lying on open rock

Where icy rivers charged from mountains

And over his head icicles hung,

Sharp and hard. (SGGK 726-33) 
Rudd points out that in these passages we are seeing the Wirral through Gawain's eyes, and that the wilderness, in line with Cronon's socially constructed wilderness, has more to do with the values Gawain ascribes to it than the reality.

It is possible that Gawain himself needs this land to be strange; he needs the adventure in an Other world to secure his own identity as a questing knight of Arthur's court. As before, we are uncertain how much of what we read reflects Gawain's view and how much is the allegedly neutral description of the poem. (Rudd 60)

With its mix of real and faerie geography, perhaps $S G G K$ is showing anxiety at the possibility of a shrinking world, and the rapid deforestation hacking away at England's few remaining wilds. Without the fear of the enemy hidden beyond the dark woods, what is the purpose of a militarized aristocratic class? Wilderness re-emerges here as a necessary Other for human identity. $S G G K$, as a transition piece, is trying to contend with the realities of place instead of its conceptualized otherness, but is not yet ready to make the leap.

The historical reality of the Wirral around the late fourteenth century is like much of the rest of England. It was disafforested in 1376, but not before gaining a reputation for being a home of outlaws; ironically, the royal forest laws kept out the general population, providing criminals a relatively undisturbed haven (Rudd 56). It makes sense for Gawain to seek out the Green Chapel here, in what Gawain would consider the wildest of areas (Rudd 116). What Rudd and other critics wish to know is if Gawain himself is aware of the changes happening in the real Wirral.

Moreover, while we, the audience, may be aware of this change in the Wirral's forest status and are free to speculate about its effects, is Gawain aware of it? Gawain himself comes from a time before 1376, although as a figure of romance he is also always already 
riding through the actual landscape of the time of the poem's composition. So the question becomes one of readership, a question in which Gawain himself is also a reader of the landscape. Is the landscape he is reading the same as that being read by the poem's audience? In other words, is the poem assuming an audience that does know about the disafforestation of the Wirral, but a protagonist that doesn't? From this a further question arises: are we in the real Wirral at any point at all or only ever in the Wirral of romance imagination? (Rudd 57)

Gawain emerges from this perceived wilderness to encounter Hautdesert; the castle, though an invention of war, is described more beautifully and hospitably than the woods that preceded it. "With rows of battlements, and turrets, and beautiful / towers for sentries, and lovely loophole / Windows..." (SGGK 790-93). Saunders argues that the ambiguity of the forest's physical reality is a function of the narrative structure of the poem, even going as far as stating that Hautdesert and its wilderness operates on a different logic where threats is treated as no more than sport (154). It recalls Martin's framework of chivalric violence as play, whereby the exchange games are justified as a necessary trial of Gawain's honor, no other explanation given or needed. Since Hautdesert is located within this quasi-faerie landscape of romance, it operates as the testing ground for the journeying knight, but readers - and Gawain himself - do not realize this until the trick is unveiled (151). Saunders writes,

... while the castle's surroundings may be realistic, the final revelation of the name of the castle, signifying high desert or wasteland, seems to relate it to the Grail Castle, set far within the Waste Forest, and thus to place it once again within the world of romance. This characterization of Hautdesert as a locus of testing and adventure is, however, kept hidden from the reader until the end of the poem. Instead the narrative leaves the nature 
of the castle ambiguous, presenting it as a refuge from the forest and the winter, and as a place in which the feast of Christmas may be kept by Gawain.

The narrative thus subverts the conventional pattern of the quest within the forest: it is just when Gawain appears to have surmounted the physical obstacles of his quest through the forest, including all manner of archetypal romance enemies, from giants to wild men, that he falls into the greatest danger. (151)

Gawain, sizing up Bercilak, "judged him to a worthy knight," and allowed his host to treat him with generosity - it is here where Gawain believes he has returned to a courtly domain ( $S G G K$ 843). As it was at Arthur's court, Gawain enjoys the splendor of good food and luxury. Believing he has an ally in Bercilak, Gawain agrees to the exchange of winnings provided he is able to go to the Green Chapel at the appointed time. Thus the exchange of winnings subplot unfolds from the ruse.

Most scholars have paid attention to how the bedroom scenes bring to light an internal conflict of chivalric courtesy. Gawain must satisfy the attentions of Lady Bercilak while remaining chaste and loyal to his host Sir Bercilak. As Andreas H. Jucker summarizes in "Courtesy and Politeness in Sir Gawain and the Green Knight,"

... the laws of courtesy impose contradictory demands on Gawain. The lady explicitly refers to courtesy that should have been a motivation for Sir Gawain to give in to her advances. Gawain's restraint is interpreted as discourteous, perhaps even an insult towards her, the lady of the house. At the same time, Gawain is aware that giving in to her temptations would be an extreme act of discourteousness and disloyalty towards his host, Sir Bertilak de Hautdesert. (Jucker 12-13) 
While Gawain's situation in the bedroom scene operates as a moral test at one level, readers must be careful not to ignore the material dimension of the exchange game. Duels and jousts between knights usually result in a prize - decoration served as commodified gallantry. From the beginning of the game then, Bercilak is inverting the process; whereas before material and political power were left up to the strongest to grab, now Gawain must give up what is gained and cooperate with a trickier set of rules. That trickery quite literary follows him to the bedroom. After each day, when the castle reconvenes to feast together, Gawain is forced to confront the violent source of his sustenance, for Bercilak recounts the tales of his hunts to Gawain as they dine (SGGK 1626-30). Finally, on the third day, Lady Bercilak offers Gawain a ring, which he denies.

Explaining that until

by the grace of God,

He was able to end the adventure he'd begun,

He could never touch either gold or treasure. (SGGK 1836-38)

Gawain, who believes he is about to die anyway, has no need of material possession, and if he did, he would have to return it to Bercilak anyway. The correct choice is also the easy choice in this case.

The green girdle, however, holds a greater temptation. Lady Bercilak tells Gawain the girdle, like Excalibur's scabbard in other Arthurian legends, allows the wearer to survive any injury, and given that Gawain had witnessed the Green Knight walk off his own beheading as if it were a bruised ankle, it wouldn't appear too suspicious in the world of the poem. The rules of the exchange game require that the player give up the prize, and despite the reader's ability to see past the game, Gawain fails to sleuth out the deception. S. J. Sprouse, in "Two Sets of two 
Hunters: The Illusion of Gomen in Sir Gawain and the Green Knight," argues that, while readers and critics would identify Lady Bercilak as the hunter and Gawain the prey, Gawain's lack of awareness of the game's true intent lulls him into gullibly assuming that he is the hunter inside of Bercilak's house (Sprouse 164). We can find evidence of this in Gawain's arrogant and teasing reply to Bercilak's question regarding the origins of the kiss prize.

"No," said Gawain, "we said nothing of that.

You've had what I owe you: there's nothing more

To claim."

They laughed, and were gay, (SGGK 1395-98)

Although Bercilak later attributes Gawain's moral failure to the "love of [his] life," Gawain goes on to curse cowardice and greed, saying "They shatter chivalry, their vice destroys / Virtue" (2368, 2375-76). Therefore, readers can't ignore the material dimension of toxic masculinity that $S G G K$ is attempting to address. Materialism, decor, is too closely associated with the false grandeur and pride that the poem disdains.

If the exchange of winnings challenges the toxic masculine practice of possession, then the exchange of blows subverts the convention of violence. Victoria Weiss, in "Gawain's First Failure: The Beheading Scene in Sir Gawain and the Green Knight," points out that the delivery of the stroke in Part One is up to Gawain's discretion, and since Gawain need not deliver a deathblow, readers should understand his handling of the situation as excessively violent (Weiss 362). This reading cleanly explains why the Green Knight's returned only a merciful nick to Gawain's neck instead of cleanly decapitating him.

Gawain recognizes now what he did not recognize when presented with the challenge in the first fitt - that the terms of the agreement do not call for decapitation. Gawain realizes 
that by sustaining a mere nick, he has fulfilled the terms of the challenge. The slight scratch represents a viable alternative to the attempted death blow Gawain delivered in the first fitt. (Weiss 365)

The Green Knight is attempting to exemplify to Gawain, and the rest of Camelot, the value of mercy. That is why, despite having ties to the witch Morgana, Sir Bercilak is able to bid farewell with a Christian blessing - he was instilling in Gawain the lesson of self-sacrifice for the benefit of others, a lesson taken directly from the most crucial episode of the Christian cosmology. As a result, Gawain's conception of knighthood shifts the judging criteria away from acts of valor and displays of largesse, and instead moves it towards acts of empathy and humility (365-66). In other words, the Green Knight is giving Gawain a crash course in self-control, which lends to a greater degree of interiority and moral consideration of others. Here, there is a renegotiation of masculinity as restraint, where before it was solely marshal prowess and valor, as expressed with violence. A new definition of civility emerges with this courtly ideal of restraint and selfmoderation, whereas before it was defined primarily through the binary opposition in the physical geographic differences between human spaces and the wildernesses of nature. It is not a paradigm shift, but rather a marked point in the transition from toxic masculinity towards a more civil masculinity. In terms of the land ethic, it is a development of the second stage with implications for establishing the third stage of increased ecological consciousness.

Environmentally sound behavior is often described in restrictive terms; organizations worldwide are concerned with reducing their 'footprint,' but manhood, through capitalist ambition, demands that one 'leave one's mark on the world.' These are simply metaphors, but they illuminate the fact that twenty-first century masculine identities, immersed in consumer culture, have yet to reconcile a way of asserting one's selfhood without marking something else. 
The kind of marking that consumerist, capitalist practice involves usually results in vandalism, even if the vandalism is thousands of miles beyond the sight of the perpetrator. Conversely, one's mark could be a very green mark; one such green project that the United States happens to sorely need at this time is the construction of sustainable infrastructure, yet the likelihood of this happening is next to zero because of the heated political contests over fiscal policy and anything related to climate change. Morgana and Bercilak bring Gawain to change by humiliation; ultimately, shaming masculinity will not work. This much is confirmed in the denouement of SGGK where it is apparent that Gawain has not completely learned his lesson. In addition to his tirade that blasted women for tempting man to sin, his way home entertains "adventures" and "victories" that probably involve the slaughter of men and beasts alike (SGGK 2482). But Gawain does experience development - he acknowledges that his mistake came from "the cowardice, the greed that came to [his] soul," and he pledges to wear the green girdle as a reminder of his fallibility (2508). $S G G K$ gives us one final hint in the effort to green masculinity as demonstrated through the Round Table's adoption of the green girdle as a fraternal badge and memento. Rather than allow him to experience shame in isolation, they reaffirmed Gawain and integrated the lesson into their chivalry. The key, it seems, is both humility on the part of the individual, and affirmation on the part of society. Rather than coerce change, people are most open when they feel safe and accepted; this has no exception in knights and men. This has relevancy in today's world, where thousands of men are flocking to a growing white nationalist community that brands itself as "alt-right," with its promise of ethnic and national pride. It reminds us that America has a long unaddressed problem with nationalism, a discourse that often fails to address the realities of the global world we live in today. Returning to Bell and Braun's study of environmental justice activism in Appalachia, one such data point they explicitly discuss 
is that a common factor among the few men who do engage in coalfield environmental justice activism tend to have spent significant time - 5 to 30 years - living outside of Appalachia (80809). Just as Gawain is transformed by the journey, so too are we all; many Americans do not understand enough about the world abroad to know that many aspects of our politics, climate change and environmental issues especially, do not follow the global norm.

Lastly, looking at modern film as a popular medium and identity-shaping force, we can find examples of male protagonists that, like the Green Knight or Gawain, show varying degrees of intimacy with nature that tie into their expressions of a masculinity. Let us then consider Jack Sully, the protagonist of James Cameron's Avatar. Jake, a paraplegic and former marine, starts the film on a mission to negotiate mineral rights with an indigenous population of blue humanoid aliens, the $\mathrm{Na}^{\prime} v i$. By experiencing $\mathrm{Na}$ 'vi life in his $\mathrm{Na}$ 'vi avatar body, which has dreadlock-nerve tentacles that allow him to connect his senses to the senses of all other life forms on planet Pandora, Jake comes into a greater awareness of the ecosystem around him. When the human military attacks and forcibly evicts the Na'vi from their giant tree home, Jake joins the $\mathrm{Na}$ ' vi resistance, permanently transferring his consciousness into his $\mathrm{Na}^{\prime}$ vi avatar. Although Jake has greatly detoxified himself by the end of the film, he has ultimately given up on his humanity. While one interpretation is that he has become more human in challenging colonial exploitation and becoming $\mathrm{Na}$ 'vi, he has also physically cast aside his human body to live as another type of creature. The abandonment of his human body suggests that it is impossible for humans to coexist with the non-human, or the colonizer with the colonized. If we, as a society, want to integrate the natural environment into our consciousness and develop Leopold's land ethic, we must seek thinking that posits human and non-human as mutual agents in global and local ecosystems. 
The other protagonist I will discuss is Prince Ashitaka of Hayao Miyazaki's Princess Mononoke. Ashitaka is similar to Gawain and the Green Knight because he is a valorous warrior of antiquity, belonging to the distant past of feudal Japan. Ashitaka even rides on a steed like a knight; but he rides on an elk, not a horse. Ashitaka takes great care of his animal partner, Yakul, in the film, illustrating that Ashitaka's moral consciousness extends outward to include animals, a critical component of Leopold's land ethic. When Ashitaka contracts a terminal curse from killing a sickly, rampaging animal deity, Ashitaka journeys west to the forbidden forest, where he hopes the forest god will cure him. In the process, he is caught up in a conflict between the animal deities of the forest and the humans living in the village of Irontown, which is rapidly clearing forest to continue its mining operations. The ruler of Irontown, Lady Eboshi, employs women and lepers in iron-smelting factories, giving them a safe place to live, free from discrimination. The technology and weapons these otherwise marginalized people produce protect the village from the warring samurai; however, the animal deities, led by the wolf deityraised human, San - who is also Ashitaka's love interest in the story - frequently raid the Irontown mining operation to protect their forest. Ashitaka does not take sides in this conflict, opting to consider all viewpoints equally. As it turns out, Lady Eboshi was the one who maimed the animal deity that in turn cursed Ashitaka, but he does not retaliate against Irontown. As the conflict escalates between Irontown and the animal gods, Ashitaka works to forge peace between them. Ashitaka's diplomacy between the interests of human and non-human make him particularly applicable as a model for green masculinity. He is a strong, noble, traditionally masculine character who seeks compromise and practical solutions for all. Throughout the film, though willing to understand the actions of Eboshi and Irontown, Ashitaka vehemently protests actions that lead to long-term negative outcomes, such as the hunting of the forest god, which 
Eboshi plans to offer to the Emperor in order to guarantee Irontown's independence. Ashitaka understands that the natural world must thrive in order for the human world to thrive - he is able to think more globally than the narrow interests of Lady Eboshi and the Emperor, who are enveloped in their local conflicts. In the film's conclusion, Ashitaka and San choose to live separately, her in the forest, and him in Irontown, showing that he can still prioritize human interests without condemning the non-human world. In today's political climate, this sort of compromise is sorely needed, yet impossible. We can't read a Japanese film, even if it is modern, as an indicator of Western attitudes, but it does offer an important point of comparison to how the rest of the world reconciles this issue. It is somewhat ironic that, although ten years older than Avatar, Princess Mononoke does more to deconstruct the human/non-human binary than the film that is literally and figuratively about leaving the bounds of humanity.

Between the protagonists of these two films, the good news is that they are indeed protagonists, and not antagonists like the Green Knight. As climate change becomes an increasingly important issue for our world, our cultures will respond with more environmental literature and stories. We can have very traditionally masculine characters, but we must put them to work improving themselves. Expressions of masculinity that rely on negative, hierarchical connotations must be avoided - narratives that feature a character 'breaking the mold,' so to speak, should be encouraged over those that assert the status quo. Avatar and Princess Mononoke are both positive in that regard; whereas the typical romance pattern ends with the knight's return, the protagonists of either film do not. They find a new equilibrium - and home - inside the wilderness that they enter, overcoming Cronon's wilderness problem by becoming the primary agents responsible for maintaining the ecosystem's health, asserting humanity's role as global ecosystem engineers. They also manage to accomplish this feat without falling into an 
impossible pastoral vision; Ashitaka chooses to live in iron town as opposed to the forest where his lover resides, seemingly wild and free. Jack and the Na'vi must fend off giant predators every day; they domesticate animals and colonize trees to form communities. Final peace with nature is not achieved in either film; however, the characters are left with the future in their hands.

The Green Knight, although greener in some regards than Gawain, may not be suitable as a model for green masculinity at all. Northrup Frye, in The Secular Scripture, writes that the romance narrative, with its motif of the journey at the center, remains today as the vehicle through which we understand our own lives. "Literature is an aspect of the human compulsion to create in the face of chaos," he writes, and "Romance is the structural core of all fiction," with its core narrative being "man's vision of his own life as a quest" (Frye 15, 31). We readily identify with the romance protagonist, even if he is as sexist and violent as Gawain is in $S G G K$, because his wanderings and adventures relate to our own continuous struggle. Frye, just like Leopold, uses "man" as shorthand for the whole of humanity, revealing that, even now, the romance protagonist is still almost always male. Disney movies have incorporated more female protagonists in recent years, and many of Miyazaki's films star courageous and kind heroines. The expansion of the female main character in film is a trend I sincerely hope continues, as well as the trans and mix-gendered protagonist, which we almost never see out of Hollywood. The simple act of identification with a protagonist that differs from the reader or viewer - let us say, a five year old boy living in coal country - might expand his range of empathy. If we are to consider masculinity as a collection of values and attitudes, then surely our boys can pick up these lessons from women as easily as they do from men. Leopold's land ethic, after all, is essentially an increase in mindfulness. But it is not just Gawain's status as the protagonist that makes him more relatable; Gawain remains closer to our experience, regardless of gender, as 
first-world citizens, where the effects of deforestation, pollution, and environmental degradation exist comfortably outside of our daily lives; that is, until they come bursting in all at once, hulking green, and forcing us to make some uncomfortable decisions. For a great many poor and people of color, however, who unjustly confront a greater proportion of environmental risk, the case is so that they will easily perceive what is necessary to guarantee a healthier and more prosperous future for all. It reminds us that toxic masculinity is intricately tied with privilege, sometimes patriarchal, sometimes racial, and sometimes economic.

We should also be prepared for green masculinity to be resisted, twisted, and joked upon by mainstream or conservative forces. As Garrard warns in the following passage, tropes can backfire on creators to meet the political goals of the retaliator, whether they are progressive, green, toxic, or conservative.

Another crucial feature of rhetoric is that tropes are assumed to take part in wider social struggles between genders, classes and ethnic groups. Cultures are not shaped equally by all their participants, nor are the many world cultures equally powerful, and we must remain aware that even tropes that might potentially confront or subvert environmentally damaging practices may be appropriated. (Garrard 9)

As Garrard suggests, the culture war over the definition of masculinity will continue as it always has, and it will fall on individuals to do what they can; after all, this is not just a fight to save the planet, but it is also an addressal of rape culture and gender equality. There is simply too much at stake.

The poet of $S G G K$, considering the poem's moralized and Christianized tones, clearly intended to change conceptions of masculinity in order to adapt to the conditions of the time. As the feudal era came to a close, the poet recognized a more civilized definition of masculinity was 
required for a more modern society. Rather than write a typical romance that concluded with an epic battle, $S G G K$ is a moral contest that pits Gawain against his own desires - and as this paper has argued, the destructive impulse of toxic masculinity informs these desires. The poet uses the convictions of the Christian religion to support his message, as this was the cultural tie connecting Western Europe. America today is not unified by religion; in some regards, we are not even united by common values anymore either. However, there is a historical canon and national character ripe for application. Just as protest and dissent have been renegotiated as expressions of patriotism in these last few years, so too does the opportunity exist to retool environmental messaging. New environmentalists are coming more and more from the environmental justice movement, with its high concern for urban pollution and inequity. Climate change policy can be found in red states disguised as sustainable initiatives, energy efficiency, and infrastructure modernization programs. Economic messaging along the lines of 'ecosystem services' appeals to some; yet it is underdeveloped, especially in tandem with patriotic messaging. If toxic masculine behavior boils down to the need to express dominance, as the text of $S G G K$ leads me to believe, then there is an opportunity to tap into the competitive nature of American masculinity. While I hesitate to rile up additional nationalistic sentiment, it is that very fervor that put man on the moon. Were the United States to approach climate change and ecosystem decay with the same competitive energy put forth toward space travel or the Olympics during the Cold War, we would not currently be falling behind China as the world leader in renewable energy. The Green sector is the industry of the future; losing this boon to a masculine identity crisis is not only hypocritical of that national character, but would also cripple our economic advantage in the coming century. Conversely, since lobbied interests have such a grip on the politics of climate change, there may be little hope in the accomplishment of this 
marshaling of patriotism. President Barack Obama spoke for years on the challenge and opportunity that climate change presented, and while the majority of Americans know about the existence of anthropogenic global warming and the necessity of addressing it, the challenge was not embraced on all sides, especially compared to the success of the environmental movement in the seventies, which resulted in a bipartisan flurry of new policy. The difference between the original environmental movement and that of today is simply one of activism and prioritization. Then, the effects of pollution were so visible that it found its place on the national agenda through sheer grassroots momentum. We must realize that nothing will change, ultimately, until voters penalize candidates that campaign against responsible climate change policy. This will not happen without structured, local, vigorous organizing. And it will not change until we address the gendered discrepancy in environmental attitudes. 


\section{Works Cited}

Aberth, John. An Environmental History of the Middle Ages: The Crucible of Nature. London: Routledge, 2013.

Bell, Shannon, and Yvonne Braun. "Coal, Identity, and the Gendering of Environmental Justice Activism in Central Appalachia." Gender \& Society 24.6 (2010): 794-813. JSTOR, www.jstor.org/stable/25789907.

Brough, Aaron R., et al. "Is Eco-Friendly Unmanly? The Green-Feminine Stereotype and Its Effect on Sustainable Consumption.” Abstract. Journal of Consumer Research 44.4 (2016): 567-82. Oxford University Press Journals Online, doi: 10.1093/jcr/ucw044.

Burnley, J. D. "The Hunting Scenes in 'Sir Gawain and the Green Knight'." The Yearbook of English Studies 3 (1973): 1-9. JSTOR, www.jstor.org/stable/3506850.

Cameron, James. Avatar. Twentieth Century Fox, 2009.

Cronon, William. "The Trouble with Wilderness; or, Getting Back to the Wrong Nature." Uncommon Ground: Rethinking the Human Place in Nature, New York: W. W. Norton \& Co., 1995. 69-90. Web. Accessed 16 December 2016. www.williamcronon.net/writing/Trouble_with_Wilderness_Main.html.

Dinshaw, Carolyn. "Ecology." Turner, Marion. A Handbook of Middle English Studies. Malden, MA: Wiley-Blackwell, a John Wiley \& , Ltd., publication, 2013, pp. 348-62.

Funk, Cary, and Becka A. Alper. "Religion and Views on Climate and Energy Issues." Religion and Science: Highly religious Americans are less likely than others to see conflict between faith and science. Pew Research Center. 22 Oct. 2015. 32-41. Web. Accessed 5 Jan. 2017. www.pewinternet.org/2015/10/22/religion-and-views-on-climate-and-energyissues/. 
Francis. Encyclical Letter. Laudato si'. 24 May 2015. Web. Accessed 22 March 2017.

Frye, Northrup. The Secular Scripture. Cambridge: Harvard University Press, 1976.

Garrard, Greg. Ecocriticism. London: Routledge, 2004.

Hoffmann, Richard C. An Environmental History of Medieval Europe. Cambridge: Cambridge University Press, 2014.

Jucker, Andreas H. "Courtesy and Politeness in Sir Gawain and the Green Knight." Studia Anglica Posnaniensia 49.3 (2014): 5-28. ProQuest. doi: 10.1515/stap-2015-0007.

Leopold, Aldo. "The Land Ethic." Emergence: Complexity \& Organization 14.1 (2012): 59-86. EBSCOhost, search.ebscohost.com/login.aspx?direct=true $\& d b=b u h \& A N=74740474 \&$ site=ehost-live.

Martin, Carl Grey. "The Cipher of Chivalry: Violence As Courtly Play in the World of Sir Gawain and the Green Knight." Chaucer Review: A Journal of Medieval Studies and Literary Criticism 43.3 (2008): 311-29. Project MUSE, muse.jhu.edu/article/254745.

Merchant, Carolyn. The Death of Nature: Women, Ecology, and the Scientific Revolution. San Francisco: Harper \& Row, 1980.

Miyazaki, Hayao, director. Princess Mononoke. Studio Ghibli, 1999 (USA).

Palti, Kathleen. "The Bound Earth In Patience and Other Middle English Poetry." Isle: Interdisciplinary Studies in Literature and Environment 20.1 (2013): 31-51. Oxford University Press Journals Online, doi-org.echo.louisville.edu/10.1093/isle/ist001.

Putter, Ad. "The Ways and Words of the Hunt: Notes on 'Sir Gawain and the Green Knight, the Master of Game, Sir Tristrem, Pearl," and 'Saint Erkenwald." The Chaucer Review 40.4 (2006): 354-385. Project MUSE, doi:10.1353/cr.2006.0008. 
Quammen, David, and Kris Ellingsen. The Song of the Dodo: Island Biogeography in an Age of Extinctions.New York: Scribner, 1996.

Rudd, Gillian. "'The Wilderness of Wirral' in Sir Gawain and the Green Knight." Arthuriana 23.1 (2013): 52-65. Project MUSE, doi:10.1353/art.2013.0005.

---. Greenery: Ecocritical Readings of Late Medieval English Literature.

Manchester, UK: Manchester University Press, 2007.

---. “Being Green in Late Medieval Literature.” Turner, Marion. A Handbook of Middle English Studies. Malden, MA: Wiley-Blackwell, a John Wiley \& , Ltd., publication, 2013, pp. 27-38.

Saunders, Corinne J. The Forest of Medieval Romance : Avernus, Broceliande, Arden. Cambridge: D.S. Brewer, 1993.

Savage, Henry L. "The Significance of the Hunting Scenes in Sir Gawain and the Green Knight." The Journal of English and Germanic Philology 27.1 (1928): 1-15. JSTOR, http://www.jstor.org/stable/27703094.

Shippey, T. A. "The Uses of Chivalry: 'Erec' and 'Gawain.”' The Modern Language Review 66.2 (1971): 241-50. JSTOR, www.jstor.org/stable/3722880.

Sir Gawain and the Green Knight. Translated by Burton Raffel. Signet Classics. New York: Penguin, 2009.

Sprouse, S. J. "Two Sets of two Hunters: The Illusion of Gomen in Sir Gawain and the Green Knight." Comitatus: A Journal of Medieval and Renaissance Studies 47.1 (2016): 163 88. Project MUSE, doi:10.1353/cjm.2016.0045.

Thomas, Keith. Man and the Natural World: Changing Attitudes in England 1500-1800. Harmondsworth: Penguin, 1984. 
Twomey, Michael. "How Green was the Green Knight? Forest Ecology at Hautdesert." Arthurian Literature 30 (2013), 27-54. Academia. Web. 13 January 2017.

Weiss, Victoria L. "Gawain's First Failure: The Beheading Scene in Sir Gawain and the Green Knight." Chaucer Review: A Journal of Medieval Studies and Literary Criticism 10.4 (1976): 361-66. JSTOR, www.jstor.org/stable/25093365.

Young, Charles R. The Royal Forests of Medieval England.Philadelphia: University of Pennsylvania Press, 1979. 